\title{
AN INTRODUCTION TO DIRECT FOREIGN INVESTMENT IN MEXICO
}

\section{A CONTEMPORARY AND HISTORICAL LEGAL ANALYSIS OF MEXICAN DIRECT FOREIGN INVESTMENT LAWS AND POLICIES AND THEIR RELATION \\ TO THE NORTH AMERICAN FREE TRADE AGREEMENT}

\author{
Michael W. Goldman* \\ James J. Tallaksen"* \\ Michael C. McClintock" \\ Richard J. Wolkowitz".**
}

\section{INTRODUCTION}

Throughout most of the twentieth century, Mexican political thought has centered on achieving self-sufficiency. The perceived need for selfdetermination via isolationism resulted from years of oppression under Spanish rule and was augmented by United States aggression in the 1840's.' Today, however, Mexico is rapidly changing its political thought and is on the verge of becoming a major player in the arena of international trade.

Mexico's sudden shift from an isolationistic, tightly regulated economy toward a more open, free-market economy is largely the result of the work of one man, President Carlos Salinas de Gortari. In 1988, President Salinas was elected the sixty-fourth President of the United States of Mexico ${ }^{2}$ and began serving the single six-year term allowed Presidents under the Mexican Constitution. ${ }^{3}$ In early 1989 , he announced two goals: first, the pursuit of economic recovery through an economic reform program, and second, the

* B.A., 1991, James Madison University; J.D., 1994, Gonzaga University School of Law; LL.M. Candidate, 1995, Georgetown University Law Center, International and Comparative Law.

** Professor of Law, Gonzaga University School of Law, Spokane, Washington. B.A., 1965, and J.D., 1969, University of Tulsa; LL.M., 1971, and S.J.D., 1975, Southern Methodist University School of Law.

*** Manager of Employee Relations for The Stanley Works, New Britain, Connecticut. B.B.A., 1980, Western Connecticut State University; M.S., 1989, University of New Haven; J.D., 1992, Gonzaga University School of Law.

**** Member of the law firm of Husch \& Eppenberger, St. Louis, Missouri. B.S., 1990, University of Illinois, Champaign-Urbana; J.D., 1993, Gonzaga University School of Law; LL.M., 1994, Georgetown University Law Center, International and Comparative Law.

1. James E. Herget \& JoRge CamiL, AN INTROduction to the MEXICAN Legal SYSTEM 1-19 (1978).

2. Ignacio Gomez-Palacio, The New Regulation on Foreign Investment in Mexico, 12 Hous. J. INT'L L. 253 (1990).

3. See Constitución Politica de los Estados Unidos Mexicanos, tit. II, ch. III, art. 83, reprintedand translatedin Doing Business in Mexico, Part I, App. II (Andrea Bonine-Blanc \& William E. Mooz, Jr., eds., \& Norman Lopez Burton et al. trans., 1994)[hereinafter Constitution]. 
modernization of the country, society, and political debate of Mexico. ${ }^{4}$ Determined to transform Mexico into a modern nation capable of competing in an increasingly competitive, global market, President Salinas implemented major economic reforms that have taken Mexico and North America, as a whole, by storm.

\section{MeXiCo's LEGisLATIVE AND EXECUTIVE BRANCHES IN A NUTSHELL}

\section{A. The Constitution}

The Mexican Constitution, formally entitled the Political Constitution of the United States of Mexico (Constitution), ${ }^{5}$ establishes a governmental structure very similar to that of the United States. Like the United States, Mexico's government is divided into federal and state governments, each of which are administered by their respective legislative, judicial and executive officials. ${ }^{6}$ Although the states theoretically' retain all powers not expressly granted to the federal government in the Constitution, reality demonstrates that the federal government's authority is wide reaching-even more so than its United States counterpart. ${ }^{7}$

\section{B. The Legislative Branch}

Mexico's federal Congress consists of Senators and Deputies elected from the several states and the federal district. Each state and the federal district elects two Senators and a varying number of Deputies, depending on the population of the represented area. ${ }^{8}$ Enactment of legislation mirrors that of the United States Congress. Each bill must pass both Congressional houses by a majority vote before being sent to the President, who may either veto or promulgate the bill. ${ }^{9}$ If the President vetoes the proposed bill, Congress may override the veto by a two-thirds vote in each house. ${ }^{10}$ Even though Congress maintains the power to override a Presidential veto,

4. Louis Rubio, Mexico in Perspective: An Essay on Mexico's Economic Reform and the Political Consequences, 12 Hous. J. INT'L L. 235, 236 (1989).

5. The current Mexican Constitution went into effect on May 1, 1917.

6. The President, Governors and federal and state legislators are elected through universal suffrage of men and women.

7. Herget, supra note 1 , at 19.

8. Id.

9. Id.

10. Id. 
the extent of this power is quite limited. For example, in the area of direct foreign investment, federal legislation, although enacted by the Mexican Congress, does little more than "rubber stamp" Mexican presidential recommendations. ${ }^{\text {I }}$ For congressional legislation to become effective, it must first be approved and promulgated by the president, and then published in the Diario Official de la Federación (Diario Official). ${ }^{12}$

\section{The Executive Branch}

The real power behind the Mexican government lies in the executive branch. ${ }^{13}$ The undisputed power of the executive branch derives from "long standing practice, statutory and constitutional provisions, and a wellinstitutionalized tradition of near-absolute political power associated with the office of the president." ${ }^{14}$ Fundamental executive powers include the power to engage in foreign relations, control the armed services, issue regulations, appoint and remove public officials, initiate and veto legislation, and numerous others. ${ }^{15}$

Article 89(1) of the Constitution expressly grants the President the power to "promulgate and execute the laws enacted by the Congress of the Union, providing for their exact observance in the administrative sphere to its exact observance." ${ }^{16}$ More simply, this language has been interpreted to grant the President the "power to enact general rules in the form of regulations (reglamentos) ... [that] have the purpose of explaining and supplying detailed rules for the application of specific laws ....17 The importance of these regulations cannot be over-emphasized, for a valid regulation has the same force and effect of law as the federal statute to which it refers. ${ }^{18}$

The only real limitations on the President's authority to issue regulations are that they must complement and develop the law, not contravene it. These limitations were set forth by the Mexican Supreme Court as follows:

11. Sandra F. Maviglia, Mexico's Guidelines for Foreign Investment: The Selective Promotion of Necessary Industries, 80 AM. J. INT'L L. 281, 283-84 (1986).

12. Id. The Diario Official is Mexico's version of the United States' Code of Federal Regulations and is the only official repository of Mexican federal legislation. Id. at 284 n. 19.

13. Herget, supra note 1 , at 20 .

14. Id.

15. Id.

16. Constitution, supra note 3, tit. III, ch. III, art. 89.

17. HARRY WRIGHT, ForeIGN ENTERPRISE IN MEXICO 16 (1971).

18. Herget, supra note 1 , at 23. 
Article 89, paragraph 1 of our main Law, confers [upon] the President of the Republic three capacities: a) That of promulgating the laws issued by the Congress of the Union; b) That of executing said laws; and c) That of providing in the administrative sphere to its exact observance, i.e., the regulatory capacity. This last capacity allows the Executive to issue general and abstract provisions, whose purpose is the execution of the Law, developing and complementing [emphasis added] in detail the provisions included in the legislation issued by the Congress of the Union. . . . [The regulation] is an alternate norm that has its measure and justification in the law. . . [T] provides the general and abstract media, that must be used to apply the law to concrete cases. ${ }^{19}$

As evidenced by the Court's ruling, the office of the President maintains various legislative as well as traditional executive functions. It is the interplay between these two roles that makes the President the unquestioned ruler in both Mexican domestic and foreign affairs.

\section{MEXICAN DiRECT FOREIGN INVESTMENT Policies and Laws: A CRITICAL PERSPECTIVE}

Throughout Mexico's history, Mexican policy towards direct foreign investment has closely paralleled the nation's ever changing economic status, balance of payments on foreign debt, and political attitude towards foreign capital. Together, these three dynamic variables created a state of uncertainty for investors eager to invest in Mexico.

This paper examines five key stages in Mexico's history of direct foreign investment, including Mexico's (1) pre-1973 foreign investment policy, (2) 1973 Foreign Investment Law, (3) 1989 Foreign Investment Regulations, (4) 1993 Foreign Investment Law, and (5) participation in the 1994 North American Free Trade Agreement.

\section{A. Pre-1973 Direct Foreign Investment Policy}

After achieving independence in 1810, Mexico set out on a long road toward attaining its own national identity. During these developmental years, Mexican identity was shaped dramatically by U.S. military aggression

19. Tesis 404, Apendice al Semanario Judicial de la Federación, Tercera Parte 709 (Segunda Sala 1985), quoted in Gomez-Palacio, supra note 2, at 259. 
in the 1840 's, followed by foreign economic domination near the end of the century. These two phenomena set the tone for Mexican trade policy for the next 100 years.

Mexico's first attempt to implement a national foreign investment strategy began during the rule of President Porfirio Diaz (1880-1910) and continued until the end of the 1920's. ${ }^{20}$ Diaz's foreign investment model relied heavily on the exportation of primary-goods and insistence that the government play a passive role, thereby allowing the economy to be shaped by free market forces. ${ }^{21}$ Mexican officials were not prepared for the result of this economic model, which was the actual domination of the Mexican economy by foreign investors. ${ }^{22}$ This "domination" played a leading role in causing the Mexican Revolution of 1911 and the subsequent overthrow of President Diaz. ${ }^{23}$

In 1917, Mexico adopted a new Constitution ${ }^{24}$ which imposed restrictions on foreign investment. Paramount among the restrictions were the following: (1) Article 27 nationalized Mexico's mineral, water, and land resources and created a "restricted zone" which forbade foreigners from owning land within 100 kilometers of the Mexican borders and 50 kilometers of its seacoasts; (2) Article 123 transformed labor law into constitutional law; and (3) the infamous "Calvo Clause" that mandated that foreigners conducting business in Mexico waive their right to assert their status as foreign citizens as a defense to legal actions arising from their business dealings in Mexico. ${ }^{25}$

In accord with the new Constitution and the prevailing national sentiment encouraging self-sufficiency, the Mexican government assumed greater control over Mexico's economic destiny and implemented several

20. Lawrence E. Koslow, Mexican Foreign Investment Laws: An Overview, 18 WM. MITCHELl L. REV. 441, 444 (1992).

21. Fernando Sanchez Ugarte, Mexico's New Foreign Investment Climate, 12 Hous. J. INT'L L. 243, 244 (1990).

22. Foreign investment was particularly heavy in the railroad, construction, and mining sectors, and, to a lesser extent, in public utilities, banking, real estate, manufacturing and commerce. By 1911, foreign investors owned $24 \%$ of Mexican land and owned over $50 \%$ of Mexico's total wealth. Of all foreign investment in Mexico, French and British investors each held slightly less than $30 \%$ and U.S. investors held slightly less than $40 \%$. Herget, supra note 1, at 13-14.

23. Id. at 16.

24. See Constitution, supra note 3. The 1917 Constitution replaced the previous Constitution of 1857 .

25. Charles T. Dumars, Liberalization of Foreign Investment Policies in Mexico: Legal Changes Encouraging New Direct Foreign Investment, 21 N.M. L. REV. 251, 259 (1991). 
new strategies. These strategies included nationalizing ${ }^{26}$ some economic sectors while subjecting others to a new economic plan known as "Mexicanization."27 Together, these strategies virtually closed a number of industrial sectors to foreign participation. ${ }^{28}$

On July 7, 1944, Mexico's President increased restrictions on foreign investment by promulgating the Emergency Decree of 1944 (Decree). ${ }^{29}$ The Decree's purpose was twofold: (1) to improve the current state of the Mexican economy by solidifying Mexican ownership of key industrial sectors; and (2) to guard against the anticipated movement of United States post-war profits into Mexico, thereby avoiding a large currency imbalance. ${ }^{30}$ To achieve these objectives, the Decree implemented constraints on the creation, modification, liquidation, and transfer of stock in any Mexican corporation comprised of foreign investors, thus giving the government the authority to regulate the participation of foreign investors in domestic businesses. ${ }^{31}$ Overall, the Decree paved the way for further restrictions on investment which lasted until President Salinas promulgated the 1989 Foreign Investment Regulations.

\section{B. 1973 Foreign Investment Law}

In 1973, the Mexican Congress passed the Law to Promote Mexican Investment and to Regulate Foreign Investment, commonly known as the

26. For example, in the late 1930's, President Lazaro Cardenas nationalized U.S. oil companies in Mexico and created Petroleos Mexicanos ("PEMEX"). Id. at 259-60.

27. "Mexicanization" is the process which raised the minimum percentage of Mexican ownership in a company to at least $51 \%$. Id. at 260 .

28. These sectors included: sulphur mining, oil and gas exploration and production, petrochemical production, mining, transportation, fishing and forestry, radio and television broadcasting, electric power generation, and automotive parts manufacturing. Jorge Camil, Mexico's 1989 Foreign Investment Regulations: The Cornerstone of a New Economic Model, 12 Hous. J. INT'L L. 1, 6-11 (1989).

29. This Decree granted the Minister of Foreign Relations (Minister) wide discretion regarding the regulation of foreign capital. The Decree denied foreigners permission to acquire a majority ownership in forestry, cattle raising, industry, real estate, and agriculture. In 1945, the Minister compiled a list of specific industries which required a minimum $51 \%$ Mexican ownership. The Decree further required any new or existing investor to convert its business association to a "joint venture," and to comply with the above ownership percentages. Id.

30. Id. at 6.

31. AleXander C. Hoagland, JR., Company Formation In MeXico $\$$ B (1980). 
1973 Foreign Investment Law (Law). ${ }^{32}$ The Law's stated purpose was "[t]o promote Mexican investment and regulate foreign investment in order to stimulate a just and balanced development and consolidate the country's economic independence. ${ }^{133}$ Enactment of the Law represented Mexico's official acknowledgment that (1) import replacement ${ }^{34}$ policies alone were not sufficient to solve its serious economic problems; (2) Mexican manufacturers needed to produce export-oriented products and capital goods; and (3) Mexico needed foreign assistance to improve technology, stimulate investment in new industries, and manufacture goods for export. ${ }^{35}$

\section{Restrictions on Foreign Investment}

In order to achieve maximum breadth of application, Article 2 of the Law broadly defined "foreign investment" as (1) foreign corporations; (2) foreign individuals; (3) foreign companies without corporation status; and (4) Mexican business enterprises with a majority of foreign capital or in which foreigners are empowered, by any title, to control the management of the business. ${ }^{36}$

The Law also reserved certain industries exclusively for the Mexican government, ${ }^{37}$ while reserving others exclusively for Mexicans or for Mexican companies with an "exclusion of foreigners clause. ${ }^{138}$ Any industry not falling within one of the two enumerated lists was subject to

32. Ley para Promover la Inversion Mexicanay Regular Inversion Extranjera, Diario Official, reprinted and translated in DOING BusINESS IN MExICO, Part I, app. II (Andrea Bonine-Blanc \& William E. Mooz, Jr., eds., \& Norman Lopez Burton et al. trans., 1994) [hereinafter Law]. This law was a codification of policies initiated by the emergency Decree of 1944 as well as numerous regulations and special laws enacted since 1944. Herget, supra note 1 , at 65 .

33. Law, supra note 32 , art. 1.

34. The policy of "import replacement" was devised to encourage Mexican manufacturers to change from "the establishment of plants for the mere assembly or final processing of imported parts or intermediate products, into real manufacturing facilities." Wright, supra note 17 , at 84.

35. Koslow, supra note 20 , at 445 .

36. Law, supra note 32 , art. 2.

37. These industries included: petroleum and other hydrocarbons; basic petrochemicals; exploitation of radioactive minerals and the generation of nuclear energy; mining; electricity; railroads; telegraphic and wireless communications; and other activities established in specific laws. Id. art. 4.

38. These industries included: radio and television; urban and interurban automotive transportation and transportation on federal highways; domestic air and marine transportation; exploitation of forestry resources; gas distribution; and other activities established in specific laws or in regulations issued by the executive branch of the federal government. Id. 
either a set capital percentage of permissible foreign ownership or the general forty-nine percent catch-all applicable to most industries. ${ }^{39}$

\section{Administration of the 1973 Law}

In order to implement the Law and supervise foreign investment, Congress established the National Commission of Foreign Investment (FIC), which held broad discretionary power over whether and to what extent to allow foreign investment. ${ }^{40}$ The FIC's chief function was to establish rules and guidelines and to adjudicate issues raised under the Law. ${ }^{41}$ More specifically, the FIC had the authority to: (1) increase or decrease the percentage of foreign investment in different geographical or economic areas; (2) permit higher levels of foreign ownership in "exceptional circumstances;" (3) approve or disapprove any new foreign investment in a new or previously existing business; (4) consult with and coordinate the action of various agencies and branches of the Mexican government on foreign investment matters; (5) establish criteria and requirements concerning foreign investment; and (6) exercise other powers granted by the Law. $^{42}$

Foreign investors seeking majority ownership in a Mexican business enterprise needed prior approval from the FIC. ${ }^{43}$ The FIC reserved the right to allow majority foreign ownership upon a showing that the particular investment met some or all of the seventeen characteristics listed in Article 13. As a general rule, the seventeen characteristics emphasized that the investment: (1) complement national investment strategies, such as increasing exports; (2) provide new employment opportunities for Mexican workers; (3) contribute to the development of economically less developed regions; (4) respect the country's social and cultural values; and (5) assist in the country's technological research and development. ${ }^{44}$

In 1982, after nine years of arbitrary decision-making by the FIC,

39. Industries limited to a set percentage of foreign ownership included: secondary petrochemicals (40\%); manufacture of automotive components $(40 \%)$; exploitation and use of minerals (49\%) (but exploitation of national mining reserves was limited to $34 \%$ ); and those established in specific laws or regulations issued by the executive branch of the federal government. Id. art. 5.

40. The Commission was composed of the Ministers of the Interior, Finance and Public Credit, Foreign Affairs, National Resources, Industry and Commerce, Labor and Social Welfare, and the Presidency. Id. art. 11.

41. Herget, supra note 1 , at 65.

42. Law, supra note 32 , art. 12.

43. Id.

44. Id. art. 13 . 
Mexico's economy slumped due to falling oil prices. ${ }^{45}$ The net effect of this slump was a sizeable increase in Mexico's external debt, higher inflation, substantial capital flight, and a decline in Mexico's GNP. ${ }^{46}$ Faced with mounting economic problems, the FIC began a new strategy aimed toward increasing foreign investment via a gradual relaxation of Mexico's restrictive foreign investment policies.

\section{1989 Foreign Investment Regulations}

\section{Significant Steps Preceding Enactment of the 1989 Regulations}

Under the leadership of President Miguel de la Madrid, ${ }^{47}$ Mexico began reopening its doors to foreign investment. For the purpose of encouraging foreign investors to return to Mexico, President Madrid introduced the following measures:

(1) February 1984: Mexican government eliminated the fortynine percent ceiling on certain "priority sectors;"

(2) December 1985: Mexican government allowed foreign investors currently holding majority ownership interests in Mexican business enterprises to raise their ownership interests to $100 \%$;

(3) September 1986: FIC eliminated investment restrictions for small-to-medium sized business (those with less than U.S.\$60 million in annual sales, and fewer than 250 employees); and

(4) September 1986: FIC began a debt for equity swap program, generating U.S. $\$ 2.9$ billion in only thirteen months. ${ }^{48}$

These four measures were soon followed by Mexican debt-renegotiation with the International Monetary Fund (IMF) and other commercial lenders. ${ }^{49}$ In August 1986, Mexico became the ninety-second Contracting

45. Koslow, supra note 20 , at 447.

46. In 1982, Mexico's GNP declined $0.5 \%$ and in 1983 it declined 5.3\%. GomezPalacio, supra note 2, at 253. During the 1980's, Mexico's national debt exceeded U.S.\$100 billion. Salinas Assesses State of Nation, HouS. CHRON., Nov. 2, 1989, at A10.

47. Miguel de la Madrid Hurtado was president of Mexico from December 1, 1982 to November 30,1988

48. Foreign Investment Regulations, Int'l Rep., Mexico Serv., May 25, 1989, at 3-5.

49. In exchange for the IMF restructuring Mexico's debt, Mexico agreed to reduce tariffs, liberalize foreign investment, reduce public spending, institute tax reform, privatize state-owned enterprises, and reform domestic price controls. Constance A. Hamilton, United States International Trade Commission, Review of Trade and Investment Liberalization 
Party to join the General Agreement on Tariffs and Trade (GATT).$^{50}$ By joining GATT, Mexico agreed to: (1) bind its tariff schedule to a maximum level of fifty percent; (2) limit surtaxes applied to general tariffs in nine sectors and totally eliminate the surtax in eight years; (3) comply with Article VII of GATT in its customs valuation procedures and eliminate its official pricing system by December 1987; and (4) gradually eliminate its import permit requirements. ${ }^{51}$ In 1989, Mexico's new industrial policy ${ }^{52}$ received considerable confidence from foreign investors as a result of a new debt agreement, called the "Brady Plan." By agreement, the Brady Plan allowed reductions in principal and interest and the granting of new loans to developing countries, which limited public sector spending, encouraged foreign investment, and minimized subsidies to domestic industries." ${ }^{153}$

\section{Key Provisions of the 1989 Foreign Investment Regulations}

In 1989, President Salinas issued the Foreign Investment Regulations (Regulations) $^{54}$ with the ultimate objective of promoting foreign investment, thereby modernizing the Mexican economy, creating jobs, fostering competition, inducing technology transfer, increasing exports, and

Measures By Mexico and Prospects For Future United States-Mexican Relations, "Phase I: Recent Trade and Investment Reforms Undertaken by Mexico and Implications for the United States," Investigation No. 332-282, USITC Publication 2275, April 1990, ch. 1, at 1-3.

50. Dumars, supra note 25.

51. Id. at 255.

52. Mexico's national industrial policy seeks to: 1) enable the national industry to grow by developing a competitive export sector; 2 ) establish industrial development balanced with the adequate use of regional resources; 3 ) promote and protect Mexico's foreign trade interests; and 4) increase the number of productive jobs as well as improve social welfare. Ugarte, supra note 21 , at 248.

53. Dumars, supra note 25, at 258. The Brady Plan gave banks three options: 1) reduce the principal on outstanding Mexican loans by $35 \%$ with an interest rate equal to the London Interbank Offer Rate (LIBOR) plus $13 / 16 \%$ collateralized with United States Treasury Bonds; 2) lower the interest on outstanding Mexican loans to $6.25 \%$, collateralized as above; or 3) make new loans equal to $25 \%$ of the current debt with an interest rate equal to LIBOR plus $13 / 16 \%$. Debt reduction resulting from the first two options totaled approximately U.S.\$14.75 billion, and new loans made available under the third option reached U.S.\$1.5 billion between 1990 and 1992. Id.

54. Reglamento de la Ley para Promover la Inversion Mexicanay Regular Inversion Extranjera, 427 Diario Official 11, May 16, 1989, reprinted and translated in DonNG BUSINESS IN MEXICO, Appendix IV (Michael W. Gordon ed., 1991) [hereinafter Regulations]. The Regulations' proper title is "The Regulations of the Law to Promote Mexican Investment and Regulate Foreign Trade." 
advancing Mexico's ability to compete internationally." ${ }^{53}$ To accomplish these objectives, President Salinas sought to streamline foreign investment procedures by clarifying the often arbitrary and complicated existing procedures and removing much of the FIC's broad discretion. ${ }^{56}$ The Regulations had the immediate effect of repealing all previous administrative investment regulations and decrees, as well as the general resolutions of the FIC. ${ }^{57}$ The Regulations did not, however, repeal the 1973 Law. ${ }^{58}$ As a result, any business acquisition or involvement not covered by the new regulations remained subject to the forty-nine percent cap on foreign ownership.

The Regulations made five major changes to Mexico's foreign investment policy. First, they abrogated the forty-nine percent limit on direct foreign investment in "unclassified activities." Regulations, the FIC was required to grant automatic approval of up to $100 \%$ foreign ownership if the following criteria were satisfied:

(1) Investment in fixed assets could not exceed U.S.\$100 million;

(2) Investment could only be funded by foreign capital;

(3) Industrial projects could not be located in Guadalajara, Mexico City, or Monterey;

(4) Aggregate foreign exchange balances had to be anticipated to balance over the first three years of the project;

(5) Investment had to create permanent jobs and establish worker training and personnel development programs; and

(6) Investment was required to employ technology complying with environmental requirements. ${ }^{60}$

All projects not satisfying the above criteria (including those within the Restricted Area) were still required to submit to the FIC; however, the FIC was required to issue a formal response within forty-five days or approval would be deemed granted. ${ }^{61}$

55. David B. Hodgins, Comment, Mexico's 1989 Foreign Investment Regulations: A Significant Step Forward, But is it Enough?, 12 HouS. J. INT'L L. 361,366 (1990).

56. Koslow, supra note 20 , at 447-48.

57. Id. at 447.

58. Id.

59. "Unclassified activities" are those business activities which have no percentage limit on foreign investor control. These activities may be contrasted with activities which are: reserved exclusively to the state; reserved exclusively for Mexican citizens; or limited to a set percentage of permissible foreign ownership.

60. Hodgins, supra note 55 , at 366 .

61. Regulations, supranote 54 , art. 2 . The new regulations should streamline existing FIC approval procedures, which in the past took months to complete. 
Second, the Regulations permitted foreign investors, with prior approval of the FIC, to acquire up to $100 \%$ ownership in areas normally reserved exclusively to Mexicans or limited to forty-nine percent. ${ }^{62}$ Ownership rights obtained in these fields were acquired through the employment of a twenty-year temporary trust. ${ }^{63}$ Generally, use of temporary trusts was permitted only for companies in financial distress or which required substantial capital for modernizing or expanding facilities. ${ }^{64}$ Although the Regulations encouraged use of the temporary trust mechanism to stimulate foreign investment, foreign investors were nonetheless required to seek approval from the Ministry of Commerce \& Commercial Promotion (SECOFIN) to do the following:

(1) Obtain a majority interest in the capital stock of a company protected by Mexican law against majority ownership;

(2) Maintain the right to dispose of more than fifty percent of the total capital of a company; or

(3) Maintain the right to exploit the company's assets. ${ }^{65}$

Third, the Regulations created a new type of stock called neutral shares or "Series $\mathrm{N},{ }^{166}$ which permitted foreign investors, through a trust, to share in the gains and dividends but not the voting rights of the stock. ${ }^{67}$ The issuance of Series $\mathrm{N}$ stock marked a significant change from Mexico's prior investment law because it provided foreign investors access to all stocks listed on the Mexican stock exchange.

Fourth, the Regulations established specific criteria to govern all real estate trusts within Mexico's "restricted zone." ${ }^{168}$ These trusts granted

62. Koslow, supra note 20 , at $\mathbf{4 5 0 .}$

63. Regulations, supra note 54 , arts. 23, 26. Unlike the United States, the Mexican legal system does not have trusts law. In Mexico, natural persons are prohibited from acting as trustees; therefore, the role is filled exclusively by Mexican domestic banking corporation.

64. Regulations, supra note 54 , art. 23 . These temporary trusts enabled foreigners to participate in 1) air and maritime transportation; 2) gas distribution; 3) mining activities; 4) secondary petrochemical production; 5) and automotive parts manufacturing. Bill $F$. Kryzda, Mexico 's New Foreign Imvestment Law and NAFTA, in NAFTA: CrITICAL BuSINESS AND LegAL Issues, § VIII at 14 (AM. CoNF. INST., March 17-18, 1994).

65. Regulations, supra note 54 , art. 10 (I)(II)(III).

66. Id. arts. 13-15. FIC approval was necessary to obtain Series $\mathrm{N}$ stock. Also, Series $\mathrm{N}$ stock could only be issued by companies agreeing to use their stock proceeds to establish new activities or expand existing activities. Id. art. 14.

67. Koslow, supra note 20 , at 453.

68. As noted earlier, Mexico's Constitution forbids foreigners from owning legal title to land within a "restricted zone" consisting of land located within 100 kilometers of Mexico's borders and within 50 kilometers of Mexico's coastline. Constitution, supra note 
foreign investors full beneficial rights in restricted real estate. While these trusts were in existence prior to 1989 , the new regulations were designed to guarantee their continuing validity. ${ }^{69}$ Under the new regulations, real estate trusts could be extended automatically for an additional thirty years so long as the beneficiaries and trust terms remained unchanged. ${ }^{70}$ The Regulations required real estate trusts (with foreign beneficiaries) to be used exclusively for the realization of either tourist activities" ${ }^{\text {"1 }}$ or industrial activities. $^{72}$ Additionally, the Regulations required all foreign trust beneficiaries to register with SECOFIN and forbade real estate trusts holding rural land from exceeding twenty hectares without prior approval. ${ }^{73}$

Fifth, the new regulations allowed foreign investors to incorporate or acquire stock in maquiladora ${ }^{74}$ and export-oriented operations without seeking prior FIC approval. ${ }^{75}$ Additionally, the Regulations granted permission for the expansion of existing maquiladora and export-oriented operations through the implementation of new projects, product lines, or economic activities, all without requiring specific FIC authorization. ${ }^{76}$

\section{Investor Response to the 1989 Regulations}

The initial response of foreign investors to the new regulations was much more staid than the Salinas Administration had anticipated. In fact, during the first year following promulgation of the Regulations, foreign investment increased at an arduously slow rate. Legal commentators contributed this slow economic growth primarily to three key factors, including: (1) President Salinas' decision not to repeal the 1973 Law; (2) the lingering memory that Mexico nationalized its banking industry in 1982;

3, tit. I, ch. I, art. 27.

69. Dumars, supra note 25 , at 262.

70. Regulations, supra note 54, art. 20. Failure of the Secretariat of Foreign Relations to take action on the trust application within $\mathbf{4 5}$ days resulted in automatic approval.

71. Id. art. 19. Article 19 contains a complete list of tourist activities.

72. Id. arts. 16-22.

73. $I d$.

74. A "maquiladora" is "a generic term for those firms which 'process' (assemble and/or transform in some way) components imported into Mexico which are then reexported." Norris C. Clement, An Overviewof the Maquiladora Industry, 18 CAL. W. INT'L L.J. 55, 56 (1987). The Maquiladora program allows parts of items to be imported into Mexico for assembly and then returned to the United States with the United States assessing a duty on the value added by assembly in Mexico. Dumars, supra note 25, at 263.

75. Regulations, supra note 54 , art. 6.

76. Hodgins, supra note 55, at 367-68. New projects include industrial, commercial, and service facilities. Regulations, supra note 54, arts. 27-28. 
and (3) the unstable political foundation underlying Salinas' presidency. ${ }^{77}$

In 1990, however, worldwide foreign investment in Mexico began increasing sharply. In order to appreciate this dramatic growth, it is beneficial to study the chart below that divides Total Foreign Investment (TFI) in Mexico into Direct Foreign Investment (DFI) and Portfolio Foreign Investment (PFI), which comprises stock market and money market investment. Mexico's foreign investment from 1989 to 1993, in millions of dollars, was as follows: ${ }^{78}$

\begin{tabular}{lrr}
\multicolumn{1}{c}{ YEAR } & DiRECT F.I. & Portfolio F.I. \\
\hline 1989 & $3,036.90$ & 493.30 \\
1990 & $2,633.20$ & $1,994.50$ \\
1991 & $4,761.50$ & $9,870.30$ \\
1992 & $5,365.71$ & $3,553.20$ \\
1993 (1st half) & $2,736.70$ & $7,835.10$ \\
1993 (2d (est.)) & $2,000.00$ & $7,000.00$ \\
\hline 5 Year subtotal & $\$ 20,534.00$ & $\$ 40,746.40$ \\
\hline Total Combined & & \\
Foreign & & \\
lnvestment & $\$ 61,280.40$ & \\
\hline \hline
\end{tabular}

The United States was the largest foreign investor in Mexico; late 1980 's-early 1990's direct foreign investment totaled over U.S.\$11.6 billion in industrial projects alone. ${ }^{79}$ With new regulations in place, lower rates of inflation, ${ }^{80}$ and foreign investment on the rise, the Mexican Congress, with President Salinas's full support, enacted the 1993 Foreign Investment Law and solidified Mexico's position as a major player in international trade.

77. Koslow, supra note 20, at 453-54.

78. Kryzda, supra note 64, at 9-10. This chart is based on figures from the Mexican Central Bank.

79. Stuart Auerbach \& Edward Cody, Boom Over the Border: U.S. Firms Go to Mexico. WASH. POST, May 17, 1992, at Al.

80. By the end of 1993 , inflation in Mexico had fallen to $8.3 \%$, down from $159 \%$ in 1987. 


\section{1993 Foreign Investment Law}

On December 28, 1993, a new federal statute entitled the 1993 Foreign Investment Law (FIL) entered into force in Mexico, thereby repealing the restrictive 1973 Law. ${ }^{81}$ According to an official statement sent by President Salinas to Congress in November of 1993, the purpose of the proposed FIL was "to establish a new legal framework which, in full compliance with the Constitution, promotes competitiveness in the country, provides legal certainty to foreign investment in Mexico and establishes clear rules to channel international capital to productive activities. ${ }^{182}$ In effect, the 1993 FIL codifies many of the regulations promulgated by Salinas' administration in 1989, thus bringing Mexico's domestic law into symmetry with requirements established under the North American Free Trade Agreement (NAFTA). Until the President issues regulations explaining the $1993 \mathrm{FIL},{ }^{83}$ the 1989 Regulations shall continue in force, at least insofar as they do not contravene the FIL. ${ }^{84}$

The 1993 FIL may be subdivided into three broad categories, including: (1) provisions contrary to the $1973 \mathrm{Law}$; (2) provisions in accord with the $1973 \mathrm{Law}$; and (3) provisions in accord with the 1989 Regulations. ${ }^{85}$

\section{Provisions Contrary to the 1973 Law}

\section{a. Demise of the 49/51 Rule}

Perhaps the greatest departure from the 1973 Law is the demise of the 49/51 Rule, which limited foreign investors to a minority ownership position in the capital stock of Mexican companies. ${ }^{86}$ Under the terms of the new Law, foreign investors may control up to $100 \%$ of the capital stock of a

81. Foreign Investment Law, Diario Official, Dec. 27, 1993, reprintedand translated in TAX LAWS OF THE WORLD (Foreign Tax Law Publishers, Inc. 1994) [hereinafter FIL].

82. Jorge A. Vargas, Mexico's New Foreign Investment Act, 4 MEX. TRADE \& LAW REP. 7 (Feb. 1994).

83. See supra text accompanying note 17.

84. FIL, supra note 81, Transitory Article Fourth.

85. See Vargas, supra note 82 (setting forth the following tripartite analytical framework). See also Michell Nader S. \& Jorge Cervantes Trejo, MexicoLiberalizesForeign Investment Regime, MEX. TRADE \& L. REP., Mar. 1994, at 7-11.

86. Law, supra note 32, art. 5 (limiting foreign ownership to a maximum of $49 \%$, unless otherwise set forth in the Law or agreed to by the FIC). 
Mexican enterprise, subject to specific limitations set forth in the Law. ${ }^{87}$ Several of these limitations are explored in the following discussion.

\section{b. Promoting Foreign Investment}

Another departure from the $1973 \mathrm{Law}$, is the 1993 FIL's promotion of foreign trade via the elimination of most performance requirements. Prior to the new Law, Mexico often imposed numerous conditions that needed to be met before the FIC would authorize foreign investment projects. ${ }^{88}$ Under the FIL, the FIC may only consider the following criteria when evaluating petitions for foreign-owned projects in Mexico:

(1) The impact on employment and training of workers;

(2) The technological contribution of the project;

(3) Fulfillment of environmental provisions contained in the ecological ordinances governing the matter; and

(4) The project's general contribution to the increase in competency of the productive goals of the country. ${ }^{89}$

\section{c. Function of the National Commission of Foreign Investment (FIC)}

Under the 1993 FIL, membership on the FIC was altered to include the Secretaries of State, Foreign Relations, Finance and Public Credit of Social Development, Energy, Mines and State Industry, Commerce and Industrial Development, ${ }^{90}$ Communications and Transportation, Labor and Social Welfare, and Tourism. ${ }^{91}$ In addition, the FIC may invite other competent authorities to participate in its sessions. ${ }^{92}$

FIC duties changed dramatically, too, and now include: (1) setting foreign investment policies which promote investment in Mexico; (2) resolving terms and conditions of foreign investment participation in

87. FIL, supra note 81, art. 4. This Article allows foreign investors to "participate in any proportion in the capital stock of Mexican companies, acquire fixed assets, enter new fields of economic activity or manufacture new lines of products, open and operate establishments, and increase or relocate those already existing, except as provided in this Law." Id.

88. See supra note 44 and accompanying text.

89. FIL, supra note 81, art. 29.

90. The Secretary of Commerce and Industrial Development shall preside over the FIC. Id. art. 24.

91. Id. art. 23.

92. Id. 
activities regulated by Articles 8 and 9 of the FIL; (3) serving as a mandatory body for consultation in matters of foreign investment for departments and organizations in the Public Federal Administration; (4) establishing criteria for the application of legal and regulatory provisions on foreign investment through the issuance of general resolutions; and (5) all corresponding activities. ${ }^{93}$

\section{Provisions in Accord with the 1973 Law}

\section{a. Activities Reserved Exclusively to the Mexican Government}

While most provisions of the 1993 FIL reflect Mexico's desire to liberalize restrictions on foreign investment, there are notable exceptions. One of the most notable is the continued policy of reserving certain enterprises exclusively for the Mexican government. According to the 1993 FIL, the following "strategic areas" are reserved exclusively for the Mexican government: (1) petroleum; (2) basic petrochemicals; (3) electricity; (4) nuclear energy; (5) radioactive minerals; (6) satellite communications; (7) telegraph services; (8) radiotelegraphy; (9) mail service; (10) railways; (11) issuance of paper money; (12) mintage of currency; (13) control of ports, airports, and heliports; and (14) other areas expressly stipulated in applicable legal provisions. ${ }^{94}$

b. Activities Reserved Exclusively for the Mexican People or to Mexican Companies with an "Exclusion of Foreigners Clause"

In the same fashion as the activities reserved exclusively to the State listed above, the 1993 FIL also continues the 1973 Law's policy of reserving certain activities exclusively to the Mexican people, or to Mexican companies with an "exclusion of foreigners clause." activities include:

(1) domestic land transportation of passengers, tourists and cargo,

93. FIL, supra note 81 , art. 26.

94. Id. art. 5. For a list of activities reserved exclusively to the Mexican government under the 1973 Law, see supra note 37.

95. An "exclusion of foreigners clause" is defined as "[t]he convention or express agreement which forms an integral part of the by-laws of a company, by which the companies in question shall neither directly nor indirectly admit foreign investors as partners or shareholders, nor admit companies which do admit foreigners as shareholders to participate." FIL, supra note 81 , tit. I, ch. I, art. 2, para. VII. 
not including messenger and express package services;

(2) retail sale of gasoline and the distribution of liquid petroleum gas;

(3) radio and television broadcasting services, excluding cable television;

(4) credit unions;

(5) developmental banking institutions; and

(6) rendering of professional and technical services. ${ }^{96}$

Foreign investors may not participate in these activities either directly or through the use of trusts, conventions, business or statutory agreements, pyramid schemes, or any other investment vehicle. ${ }^{97}$ The only exception to this prohibition is through neutral investment. ${ }^{98}$

\section{c. Regulated Categories of Industrial Activity}

Continuing the practice of the 1973 Law, the FIL limits foreign participation in certain industrial areas to set percentages. Generally, these percentages are broken down into five brackets: 1) up to ten percent; 2) up to twenty-five percent; 3) up to thirty percent; 4) up to forty-nine percent; and 5) over forty-nine percent.

First, the up to ten percent bracket includes production cooperatives. Second, the up to twenty percent bracket includes domestic air transportation; air taxi transport; and specialized air transportation. Third, the up to thirty percent bracket includes controlling companies of financial groups; multiple banking credit institutions; securities exchange houses; and stock exchange specialists. Fourth, the up to forty-nine percent bracket includes insurance institutions; bonding institutions; foreign exchange houses; cable television; port services of pilotage to ships; manufacturing and marketing of explosives; etc. ${ }^{99}$ Fifth, the over forty-nine percent bracket requires foreign investors to acquire approval of the FIC prior to investing in any of the following activities: private education; legal services; appraisal institutions; insurance; cellular telephones; drilling of petroleum and gas wells; etc. ${ }^{100}$ However, limitations on foreign investment set forth in the fifth bracket require approval by the FIC only

96. Id. art. 6. For a list of similarly reserved activities under the 1993 Law, see supra note 38 .

97. FIL, supra note 81 , tit. I, ch. I, art. 6.

98. Id. tit. V, ch. I, art. 18.

99. Id. tit. I, ch. III, art. 7, paras. I-IV.

100. Id. art. 8. 
when the total value of a company's assets exceeds a threshold amount determined annually by the FIC. ${ }^{101}$

\section{Provisions in Accord with the 1989 Regulations}

\section{a. Automatic Approval of Foreign Investment Projects}

According to the $1993 \mathrm{FIL}$, the FIC must respond to petitions submitted for consideration within forty-five working days. ${ }^{102}$ Failure to decide within this period results in automatic approval of the petition. ${ }^{103}$ As discussed above, the FIL limits the FIC's discretion to four criteria when evaluating petitions to engage in foreign investment. ${ }^{104}$ These criteria are supplemented by additional criteria found in the 1989 Regulations, ${ }^{105}$ including: (1) investment in fixed assets cannot exceed U.S.\$100 million; (2) investment must be funded by foreign capital; (3) industrial projects cannot be located in Guadalajara, Mexico City, or Monterey; and (4) aggregate foreign investment must create permanent jobs and establish worker training and personnel development programs. ${ }^{106}$

\section{b. Real Estate Trusts within the Restricted Zone}

The FIL allows Mexican companies with exclusion of foreigner clauses, or clauses of similar import, to acquire ownership of real property within the restricted zone. ${ }^{107}$ These companies are subject to the following limitations: (1) ownership of real property intended for non-residential activities must be registered with the Ministry of Foreign Relations; and (2) ownership of real property intended for residential purposes must comply

101. Id. art. 9. See also, David A. Spencer, Mexico's New Foreign Investment Law, INT'L L. NewsL. (Int'l Prac. Sec. of the Wash. St. B. Ass'n), Aug. 1994, at 3. According to transitory section 11 of the FIL, the initial threshold amount is approximately U.S. $\$ 26,730,000$.

102. FIL, supra note 81 , tit. VI, ch. III, art. 28.

103. Id.

104. See supra text accompanying note 89 for a list of the four criteria.

105. See supra note 84 and accompanying text.

106. See supra note 55 and accompanying text.

107. Constitutional and statutory authority supporting Mexico's "Restricted Zone" is found in Article 27, paragraph I of Mexico's Constitution; the Organic Act of Article 27 of Mexico's Constitution; Article 1, paragraph XIII of the 1989 Regulations; and Article 2 of the 1993 FIL. 
with the provisions set forth in Title II, Chapter II of the FIL. ${ }^{108}$

While foreign natural persons and foreign legal entities are prohibited from acquiring legal ownership of real estate within the restricted zone, the FIL continues the practice of the 1989 Regulations by allowing such persons and entities to obtain beneficial use of immovable assets within the restricted zone. According to the FIL, the Ministry of Foreign Relations (Ministry) must issue a permit to a Mexican credit institution authorizing it to acquire rights, as trustee, on real property located within the restricted zone when its beneficiaries are either (1) Mexican companies without an exclusion of foreigners clause, or (2) foreign individuals or legal persons. ${ }^{109}$ After the Ministry has issued a certificate authorizing the trust, the beneficiaries are permitted to obtain the fruits, products, or revenue which result from operation of the enterprise. ${ }^{110}$ Finally, the FIL extends the duration of all real estate trusts from thirty years under the 1989 Regulations to fifty years. ${ }^{111}$ The renewal of trusts is virtually automatic and may continue indefinitely as long as the FIC approves.

\section{c. Neutral Investments}

The FIL continues the practice of allowing neutral investments, as first established under the 1989 Regulations. Under the new law, neutral investment is defined as "that which is realized in Mexican companies or in trusts authorized in accordance with this Title and it shall not be computed for determining the percentage of foreign investment in the capital stock of Mexican companies."112 Codification of the 1989 Regulations guarantees foreign investors continued access to the Mexican stock exchange.

\section{d. Imposition of Sanctions}

The FIL concludes with several articles addressing sanctions. Under these articles, sanctions are permitted "in the case of acts performed in contravention to the provisions of this Law" and may range from stiff fines ${ }^{113}$ to actual revocation of authorization to conduct business in

108. FIL, supra note 81 , title II, ch. 1 , art. 10.

109. Id. ch. II, art. 11.

110. Id. art. 12.

111. Id. art. 13.

112. Id. tit. V, ch. I, art. 18.

113. Civil penalties may range from U.S. $\$ 4,500$ to U.S.\$22,500, depending upon the nature of the infraction. Vargas, supra note 82, at 9. 
Mexico. ${ }^{114}$ Such revocation of authority would result in nullification of all violative acts, conventions, or business and statutory agreements. ${ }^{115}$ The Law may impose these sanctions on any person, whether a Mexican national, Mexican company, foreign national, or foreign legal entity. ${ }^{116}$

\section{e. North American Free Trade Agreement}

On January 1, 1994, Mexico entered into the North American Free Trade Agreement (NAFTA) with Canada and the United States. NAFTA does not create a common market like the European Union; rather it "creates a free trade area in which tariff and non-tariff barriers to trade are greatly reduced between the Parties." 117 By reducing barriers to trade, NAFTA should stimulate economic growth, thereby creating numerous jobs in member nations. Recent estimates predict that Mexico will spend U.S.\$16 billion on public works projects in 1994 alone. Of this spending, U.S.\$11.2 billion will be channeled into private investments, including U.S. $\$ 4.5$ billion to construct terminals and to purchase buses and cargo trucks. ${ }^{18}$ The remaining U.S.\$4.85 billion will be spent on laying 1,488 miles of new highways. ${ }^{119}$ Mexico, a nation whose workers have endured chronic unemployment, should benefit from increases in the availability or increases in the number of jobs, which should foster economic growth, discourage immigration into the United States, and create wealth, thereby enabling Mexican nationals to enjoy a higher standard of living. ${ }^{120}$

Chapter Eleven of NAFTA (the investment chapter) has three primary objectives: (1) to create a secure investment climate through the promulgation of clear rules for the fair treatment of foreign investors; (2) to remove tariff and non-tariff barriers to foreign investment by eliminating or liberalizing existing restrictions; and (3) to provide an effective means for dispute resolution between an investor and the host government. ${ }^{121}$

114. FIL, supra note 81 , arts. $\mathbf{3 7 - 3 8}$.

115. Id.

116. Vargas, supra note 82, at 9.

117. C. Johnston, Jr. et al., Summary of the North American Free Trade Agreement [Apr. 1993], Booklet 2, in Law and Practice under the GATT and other Trading Arrangements-North American Free Trade Agreements (looseleaf, Oceana Pub. Inc.), at 1.

118. Carlos E. Restrepo, You Can Buy Some Land in Mexico, But the Better Bet is in Project Development, Foreign TRADE, Aug. 1994, at 7.

119. Id.

120. Leslie Alan Glick, Understanding THE NORTH AMERICAN FreE TRADE AGREEMENT: LEgAL AND BUSINESS CONSEQUENCES OF NAFTA 3 (1993).

121. Daniel M. Price, An Overview of the NAFTA Investment Chapter: Substantive Rules and Investor-State Dispute Settlement, 27 INT'L LAW. 727 (1993). 


\section{Section A: Investment Rights, Duties, Obligations}

\section{a. Scope of Chapter Eleven}

Chapter Eleven's scope is extremely broad as it attempts to offer investors four basic protections: (1) non-discriminatory treatment; (2) freedom from performance requirements; (3) free profit repatriation; and (4) expropriation only in conformity with NAFTA's provisions. ${ }^{122}$ These protections are afforded to "investments" (both existing and future), as well as to "investors of a Party." ${ }^{123}$ Chapter Eleven's application is subject to two important constraints. First, financial services are excluded from Chapter Eleven, ${ }^{124}$ and second, Chapter Eleven provisions are subordinate to all other NAFTA-Chapter provisions to the extent the two chapters conflict or are inconsistent with one another. ${ }^{125}$

\section{b. General Chapter Eleven Investor Rights and Protections}

Chapter Eleven guarantees non-discriminatory treatment to NAFTA investors and their investments. "Non-discriminatory treatment" means that investors and their investments are guaranteed the better of: (1) treatment no less favorable than a Party grants its own investors (National Treatment); or (2) treatment no less favorable than a Party grants to investors of any other Party or non-Party (most-favored-nation treatment). ${ }^{126}$ Additionally, each Party, at a minimum, must treat investments in accord with international law, which includes fair and equitable treatment and full protection and security. ${ }^{127}$

Article 1106 states that no Party may impose or enforce performance requirements, which include, but are not limited to, requirements for:

(1) exporting a given level or percentage of goods or services;

(2) achieving a given level or percentage of domestic content;

122. Michael C. McClintock, Ch. 11 Investment by Nationals of other NAFTACountries, NAFTA OVERVIEW LeCTURE 2 (1994), at 2.

123. North American Free Trade Agreement: Final Text, Special Report, Free Trade Law Reports, CCH INT'L (Dec. 17, 1992). "Investors of a Party" means a Party, or state enterprise thereof, or a national or an enterprise of such Party, that seeks to make, is making, or has made an investment. Id.

124. Id. art. 1101. Financial Services are covered by NAFTA, Chapter 14.

125. Id. art. 1112 .

126. Id.

127. Id. art. 1105 . 
(3) purchasing, using or according a preference to goods produced or services provided in a Party's territory;

(4) relating the volume or value of imports to the volume or value of exports; and

(5) mandatory technology transfer, except to remedy a violation of antimonopoly laws. ${ }^{128}$

In this way, investment is no longer tied to local source or export requirements, which were particularly prevalent in the Mexican automotive industry. ${ }^{129}$

Chapter Eleven guarantees the unhindered transfer of funds, monies and profits, by freely allowing investors to repatriate profits to their home countries, to transfer "sales proceeds" (from selling a business or "interest" therein), and to conduct other monetary remittances. ${ }^{130}$ By the same token, Chapter Eleven does not require investors to repatriate profits. ${ }^{131}$ The only permissible restrictions on transfers may be pursuant to a NAFTAcountry's bankruptcy laws or necessary to maintain a "balance-of-payments" in the form of exchange rate ratios. ${ }^{132}$

Chapter Eleven forbids a Party from directly or indirectly nationalizing or expropriating a foreign investor's investment, unless it is:

(1) for a public purpose;

(2) on a non-discriminatory basis;

(3) in accordance with due process of law; and

(4) on payment of compensation at fair market value, including applicable interest. ${ }^{133}$

\section{c. Section A: Exclusions and Exceptions}

There are several major exceptions to Chapter Eleven. First, NAFTAgovernments may, at their discretion, refuse to grant NAFTA benefits if either of the following exceptions apply: (1) Foreign Policy Exception,

128. See also McClintock, supra note 122, at 3-4.

129. Glick, supra note 120 , at 24 .

130. NAFTA, supra note 123, art. 1109. See also McClintock, supra note 122 , at 5 .

131. Forced repatriation of profits is a long standing practice of some countries that requires the investor to incur confiscatory taxes on such remittances. McClintock, supra note 122 , at 5 .

132. The latter restriction is only permitted if an emergency exists such as "conditionality" requirements imposed by the IMF (Art. 2104). Id.

133. NAFTA, supra note 123, art. 1110. Payment of compensation must be made "without delay." Id. 
involving a non-NAFTA country with whom the NAFTA-country (a) does not maintain diplomatic relations, or (b) currently imposes economic sanctions; or (2) the "Shell" Entity Exception, where investors of a nonNAFTA party own or control an enterprise within a NAFTA-country and the enterprise has no substantial business activities within the NAFTAcountry's territory under which law it is organized. ${ }^{134}$

Second, NAFTA contains three annexes which list specific exceptions to the Chapter Eleven investment protections set forth above. Annex I lists all existing federal measures in all three NAFTA-countries which derogate from the national treatment, most-favored-nation, or performance requirement obligations of Chapter Eleven. All exceptions listed in this annex are subject to the "ratchet rule," whereby an existing rule may not be made more restrictive and, if liberalized, may not later be made more restrictive. ${ }^{135}$ Among others, Mexico reserves the following exceptions: (1) ownership of land (requires use of real estate trusts); (2) cable television; (3) federal government review of incoming foreign acquisitions exceeding $\$ 25$ million pesos (to reach $\$ 150$ million pesos over a ten year period); (4) air/land transportation; (5) retail sales of petrochemical products; and (6) privatization. ${ }^{136}$

Annex II lists specific sectors which are not subject to the "ratchet rule." These sectors include: (1) basic telecommunications; (2) broadcasting; and (3) maritime trade. ${ }^{137}$ Annex III lists special Mexican reservations which are based on its unique constitutional provisions requiring certain activities to be in the exclusive ownership or control of the Mexican State. ${ }^{138}$ All provisions listed in Annex III are subject to the "ratchet rule." 139

\section{d. Section B: Settlement of Investment Disputes}

Chapter Eleven also establishes a complex mechanism for the settlement of private investment disputes between a NAFTA-country and an investor of another NAFTA-country for alleged breaches of its NAFTA Chapter Eleven Section A obligations. This dispute settlement mechanism provides for resolution via international arbitration, rather than by a NAFTA

134. Id. art. 1113.

135. Price, supra note 121 , at $730-31$.

136. McClintock, supra note 122 , at 7-8.

137. Id. at 9 .

138. Id. at 9-10.

139. Price, supra note 121 , at 731 . 
dispute panel. ${ }^{140}$ Possible fora for international arbitration include the following:

(1) ICSID: International Center for the Settlement of Investment Disputes, if both the investor and host country are signatory parties to the ICSID Convention (currently, Canada and Mexico are not signatories);

(2) ICSID "Additional Facility" alternative resolution if only one of the NAFTA-countries is not a party to the ICSID Convention; and

(3) Ad Hoc Tribunal established under the U.N. Commission on International Trade Law (UNCITRAL) rules. ${ }^{141}$

According to Articles 1116 and 1117 , international arbitration is appropriate for both (1) alleged breaches of NAFTA Chapter Eleven obligations, and (2) anti-NAFTA behavior of government-run monopolies. ${ }^{142}$ However, neither of these claims can be brought unless there is proof of an actual direct or indirect injury. ${ }^{143}$ All claims brought under this are subject to a three-year statute of limitations. ${ }^{144}$

\section{CONCLUSION}

During the past decade, Mexico's policy toward foreign investment underwent a true economic revolution that appears sure to continue well into the next century. However, the prudent Canadian or U.S. investor recognizes that Mexico's current open-door policy may not continue if its people or resources are exploited, as Mexico's frequently changing attitude toward foreign investment has shown. Maintaining good relations with Mexico demands that investors respect Mexican cultural values and laws and be willing to engage in arms-length negotiations. By treating Mexicans as equals, Canadian and U.S. investors can almost assure themselves continued access to an ever growing market of consumers who not only need, but actually prefer, Canadian and U.S.-made goods.

140. For an excellent discussion of NAFTA Chapter Eleven Section B's dispute settlement mechanism, see ld, at 731-35.

141. McClintock, supra note 122 , at 11 .

142. Id.

143. Id.

144. Id. 
